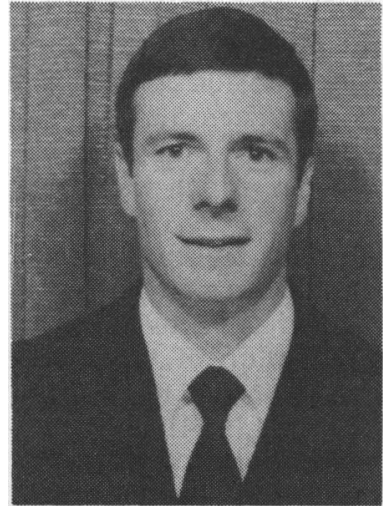

J. A. White

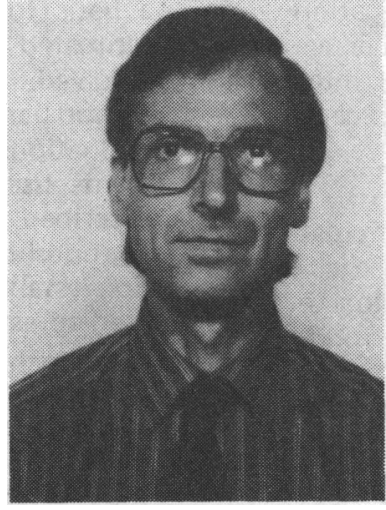

C. Ward

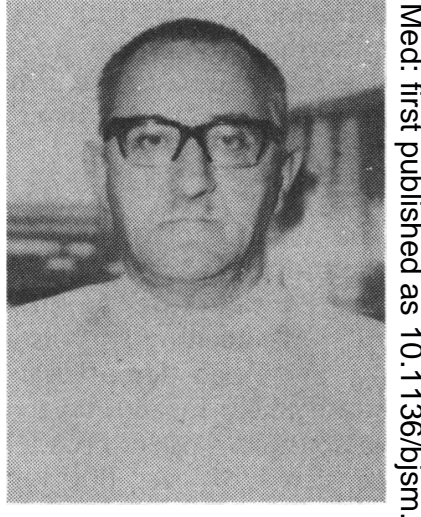

H. Nolson

\title{
ERGOGENIC DEMANDS OF A 24 HOUR CYCLING EVENT
}

\author{
J. A. WHITE, PhD*, C. WARD, MD** and H. NELSON† \\ *Department of Physical Education and Sciences, West London Institute of Higher Education, \\ Borough Road, Isleworth, Middlesex TW7 5DU \\ * "Department of Cardiology, Wythenshawe Hospital, Southmoor Road, Wythenshaw, Manchester M23 $90 \mathrm{~L}$ \\ tBritish Cycling Federation, Divisional Coaching Co-ordinator, 40 Orton Road, Wythenshawe, Manchester M23 OLJ
}

\section{ABSTRACT}

The maximal aerobic performance $\left(\mathrm{VO}_{2} \max \right)$ and energy costs of cycling at various power outputs and equivalent road speeds of a highly trained endurance cyclist (age $23.4 \mathrm{yrs}$, height $1.95 \mathrm{~m}$, weight $73.1 \mathrm{~kg}$ ), were measured in the labora-

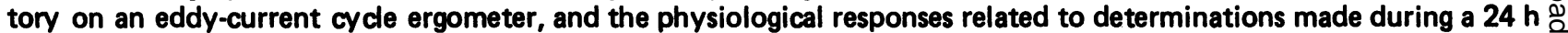
cycling time trial event, using continuous ECG recording from which estimates of ergogenic demands were obtained. $\unrhd$ The cyclist covered a distance of $694 \mathrm{~km}$ during the event at an average speed of $28.9 \mathrm{~km} \cdot \mathrm{h}^{-1}$ which corresponded to $\overrightarrow{\vec{\rho}}$

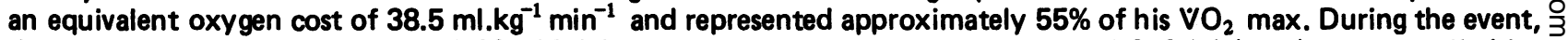
the cyclist expended an estimated $82,680 \mathrm{~kJ}$ of energy, of which approximately $44,278 \mathrm{~kJ}(54 \%)$ were supplied by repeated feedings of liquids, solids and semi-solids and some $38,402 \mathrm{~kJ}(46 \%)$ came from the stored energy reserves? which resulted in a $1.19 \mathrm{~kg}$ loss of body weight during the event. The energy demands of the activity were more than $\bar{\partial}$ three times greater than the highest recorded values of severe industrial work, and similar to the hourly rates of 0 . expenditure of shorter duration competitive events, but above the highest values reported over other extreme endurance events over the same period of time. The results thus represent near maximal levels of sustainable ergogenic 3 effort by man over a complete $24 \mathrm{~h}$ cycle.

Key words: Cycling, Ultra-distance, Physiological, Nutritional demands.

\section{INTRODUCTION}

Investigations of the ergogenic demands and nutritional requirements of prolonged endurance exercise have been the subject of many laboratory based trials aimed at optimising the physiological responses of man to several hours of continuous activity (Thomas, 1971; Thomas and Reilly, 1975; Brooke et al, 1975; Costill et al, 1976; Ivy et al, 1979 and White and Ford, 1983 and 1984). However, with the exception of the studies in

"To whom all correspondence should be addressed. runners (Lloyd et al, 1977; O'Hara et al, 1977 and Davies and Thompson, 1979) and soccer players (Reilly $\tilde{\sigma}$ and Walsh, 1981), there has been little attention to the study of extreme endurance performance under actual competitive conditions. Furthermore, even in these most recent studies the emphasis has been largely upon the work performance demands rather than the nutritional requirements of the event.

Therefore in view of the increasing popularity of "ultra-distance" competitive events but relative lack of attention focused upon the study of the specific 
demands of such activity, the present investigation was undertaken in order to estimate the relative aerobic demand, energy expenditure and nutritional intake of a racing cyclist involved in a $24 \mathrm{~h}$ road race event.

\section{METHODS}

The performance of one competitor who participated in a national 24 hour championship cycle time trial event was continuously monitored during the actual event. All time keeping and distance recording was conducted by the Road Time Trials Council officials who were strategically located on an accurately measured and wellestablished "open" road race course. The road circuit consisted of over $800 \mathrm{~km}$ of public highway class 'A' and ' $B$ ' roads and incorporated undulating terrain between $0.50 \mathrm{~m}$ elevation above sea level over the first $137 \mathrm{~km}$ of the course with the remainder between 50 $100 \mathrm{~m}$ above sea level.

Environmental conditions reflected typical seasonal (July) characteristics for northern Britain with low (night) and high (day) temperatures of $11^{\circ} \mathrm{C}$ and $16.5^{\circ} \mathrm{C}$ respectively. Prevailing winds consisted of light W/NW breeze at 12.9-16.5 $\mathrm{km} \cdot \mathrm{h}^{-1}$ which changed to a fresh W/NW wind $\geqslant 24.2 \mathrm{~km} \cdot \mathrm{h}^{-1}$ during the last 5 hours of the event. Light drizzle lasting approximately $\mathbf{3 0}$ mins occurred between 02.00 and $03.00 \mathrm{hr}$ associated with the passage of a weak cold front during the night, but other than the second weather front which brought the fresh winds during the latter part of the race, no adverse weather conditions were associated with the event, thus the environmental conditions were considered ideal for the event.

The nutritional requirements of the subject were supplied by a mobile feeding team who attended him throughout, according to the RTTC rules on $24 \mathrm{hr}$ road race events. All the necessary nutritional materials were supplied according to a pre-determined schedule as well as "on demand" feeding by the subject himself. Liquids (a commercial sports drink, sweetened tea, peppermint cocktail and assorted fruit juices), as well as semi-solids (rice pudding and fruit cocktail) were supplied in standard plastic feeding bottles, whereas solids (fruit, sweet-snacks and sandwiches) were delivered using musette containers. These techniques allowed the precise determination of volumes and weights of materials ingested and the subsequent estimation of the energy content which was determined by the use of standard food tables (Paul and Southgate, 1978).

Physiological assessment was accomplished throughout the event by continuous monitoring of the subject's heart rate using an Oxford 24 hour tape recording system (Model MR14; Oxford Medical Systems, Abingdon, England) which was conveniently located in a weather-proof pack contained in the subject's racing jersey pocket. Minute averaged heart rates were used as a basis for the calculations of physiological costs and estimated energy expenditure rates of the activity involved. Prior to the event, the subject undertook a comprehensive series of clinical diagnostic exercise evaluations, as well as functional performance assessments using standardised techniques which have been described previously (White et al, 1982). The linear relationship between heart rate and oxygen consumption established from the laboratory tests (Fig. 1) was used to estimate the oxygen costs of the activity during the event. Following the determination of the energy costs of graded exercise activity using the non-protein respiratory exchange ratio (Carpenter, 1964), the established linear regression of heart rate and energy expenditure (Sengupta et al, 1979), also demonstrated in the present study (Fig. 1), was used to estimate the energy equivalent of work performed during the 24 hour event. In this way heart rate responses reflected the physiological demand and energy cost incurred by the activity.

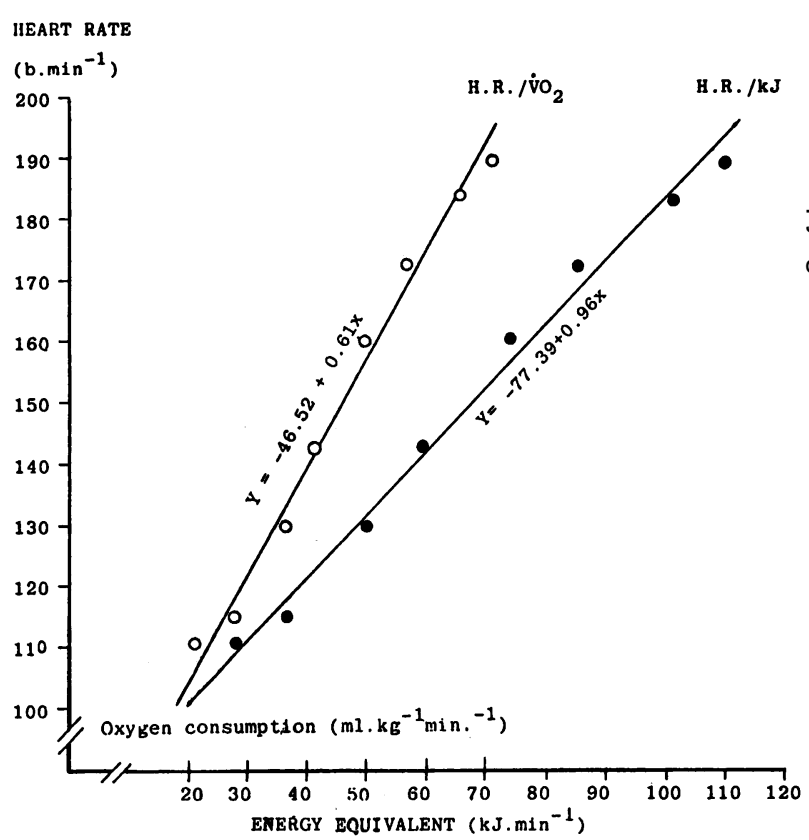

Fig. 1: Relationship between heart rate, oxygen consumption and energy expenditure during graded exercise.

\section{RESULTS}

The speed profile of the subject over the $24 \mathrm{~h}$ period is presented in Fig. 2 along with the temporal interruptions in the performance required by the necessary mechanical maintenance, body care and toiletry activities. There was a gradual decline in the cumulative average speed during the event and although the timed 


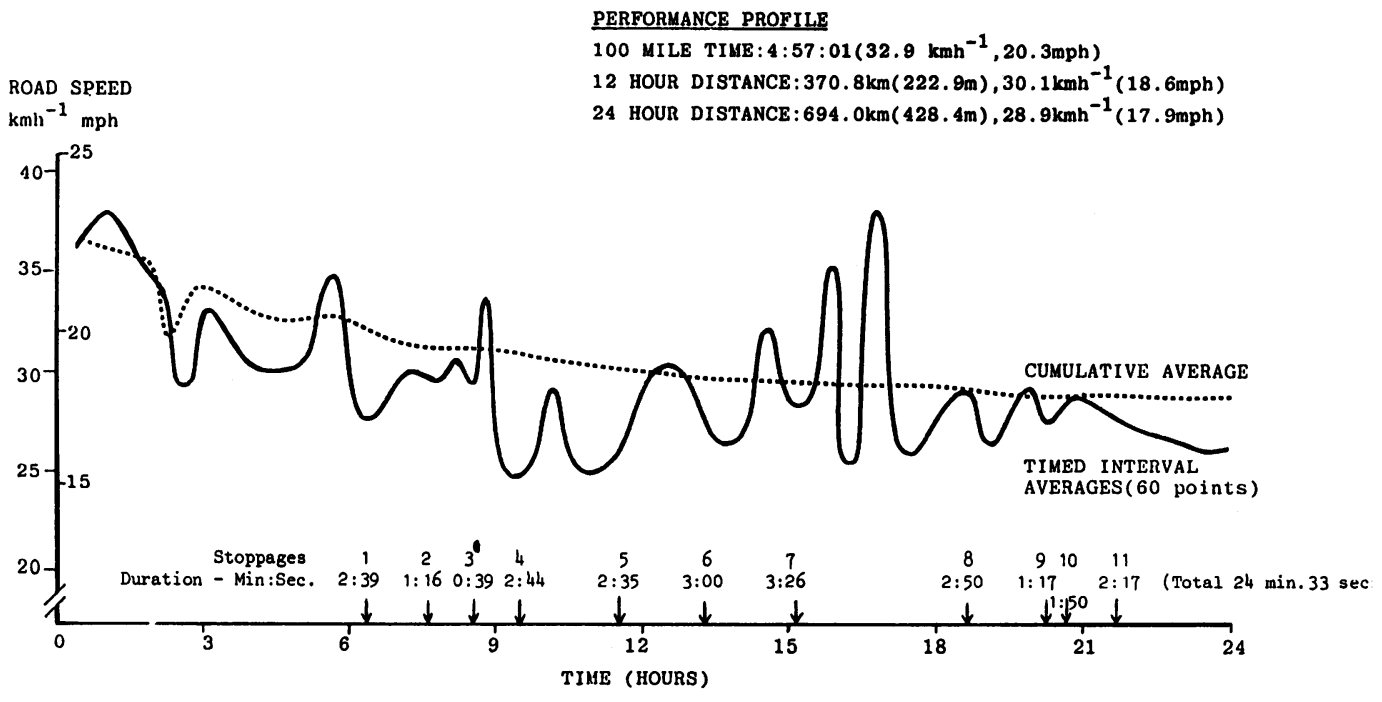

Fig. 2: Speed profile during the 24 hour cycle road race.

interval averaged speeds showed a similar decrement overall, there were considerable speed variations especially between 15-18 $\mathrm{h}$ which were attributed to both terrain and environmental influences as well as stoppages. It is interesting to note, however, that the first $161 \mathrm{~km}(100 \mathrm{~m})$ of the event were covered in a time and at an average speed which was approximately $90 \%$ of the subject's previous personal best performance for that distance (Table I).

\section{TABLE I}

Physical performance characteristics of the subject who participated in a 24 hour cycle road race event.

\begin{tabular}{llll} 
& \multicolumn{3}{c}{ Physical Characteristics } \\
Age: & $24.3 \mathrm{yrs}$ & Height: & $1.95 \mathrm{~m}$ \\
Weight: & $73.13 \mathrm{~kg}$ & Body Fat: $8.2 \%$ (estimated)
\end{tabular}

Maximal Exercise Performance Characteristics Heart rate (b. $\mathrm{min}^{-1}$ ) 189.0 Ventilation volume (L. $\mathrm{min}^{-1}$ ) 175.1 Oxygen consumption $\left(\mathrm{ml}^{\mathrm{kg}}{ }^{-1} \mathrm{~min}^{-1}\right)$ 69.9 Oxygen pulse ( $\mathrm{ml}^{\text {.beat }}{ }^{-1}$ ) 27.0 Respiratory exchange ratio 1.05 Absolute power (kpm.min ${ }^{-1}$ ) 2781.0 Relative power (kpm. $\mathrm{min}^{-1} \mathrm{~kg}^{-1}$ ) 38.0

Personal Best Cycle Road Race Performances

\section{EVENT} (miles) (km)

$5 \quad 8.05$

$10 \quad 16.10$

$25 \quad 40.25$

$50 \quad 80.50$

$100 \quad 161.00$
TIME

(hrs. min. sec.)

$0: 11: 07$

$0: 23: 41$

$0: 58: 43$

$2: 02: 07$

$4: 23: 17$
AVERAGE SPEED (mph) $\left(\mathrm{km}_{\mathrm{h}} \mathrm{h}^{-1}\right)$ 27.0 43.5 $25.3 \quad 40.7$ $25.5 \quad 41.1$ $24.6 \quad 39.6$ $22.8 \quad 36.7$
The physiological profile of the subject over the $24 \mathrm{~h}$ period is presented in Figure 3. There was a progressive decline in the absolute and relative (\% maximal) minutes average heart rates during the event with a correspondin reduction in the estimated oxygen consumption rates as well as $\% \mathrm{VO}_{2} \max$ utilised. Minor variations in heart rate and oxygen consumption levels did not affect the overall decline in both the measured and predicted parameters which tended to reflect the cumulative speed profile, and were therefore open to terrain and environmental influences as well as stoppages, all of which contributed to the observed variability.

Nevertheless it could be observed that there was a clear trend of a decline in both determined heart rate and derived oxygen consumption parameters during the first $6 \mathrm{~h}$ of the event, with heart rates reduced from $\sim 165$ b. min $^{-1}$ (88\% HR $\max$ ) to 140 b. $\min ^{-1}$ (74\% HR max) and estimated oxygen consumption reduced

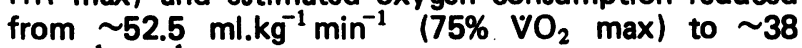
$\mathrm{ml} . \mathrm{kg}^{-1} \mathrm{~min}^{-1}\left(55 \% \mathrm{VO}_{2} \mathrm{max}\right)$. This was followed by a period of relative stability with minor oscillations in the physiological parameters between 6-18 $\mathrm{h}$ in which heart rate fluctuated around $142 \mathrm{~b} \cdot \mathrm{min}^{-1}$ (75\% HR max) and estimated oxygen consumption at $39 \mathrm{ml} \mathrm{kg}^{-1} \mathrm{~min}^{-1}$ $\left(56 \% \mathrm{VO}_{2}\right.$ max). Finally there was a further marked decline during the last $6 \mathrm{~h}$ of the event in which heart rates reduced from $\sim 132$ b. $\min ^{-1}$ (70\% HR max) to $\sim 120$ b. $\min ^{-1}$ (63\% HR max) and estimated oxygen consumption reduced from $\sim 35 \mathrm{ml}^{-k^{-1} \mathrm{~min}^{-1}}(50 \%$ $\mathrm{VO}_{2} \max$ ) to $\sim 25 \mathrm{ml} \cdot \mathrm{kg}^{-1} \mathrm{~min}^{-1}\left(35 \% \mathrm{VO}_{2} \max \right)$. The overall averages for the physiological parameters throughout the $24 \mathrm{~h}$ event involved heart rates of $\sim 142$ b. $\min ^{-1}$ (75\% HR max) and estimated oxygen consumption of $\sim 38.5 \mathrm{ml} . \mathrm{kg}^{-1} \mathrm{~min}^{-1}\left(55 \% \mathrm{VO}_{2} \max \right)$. 


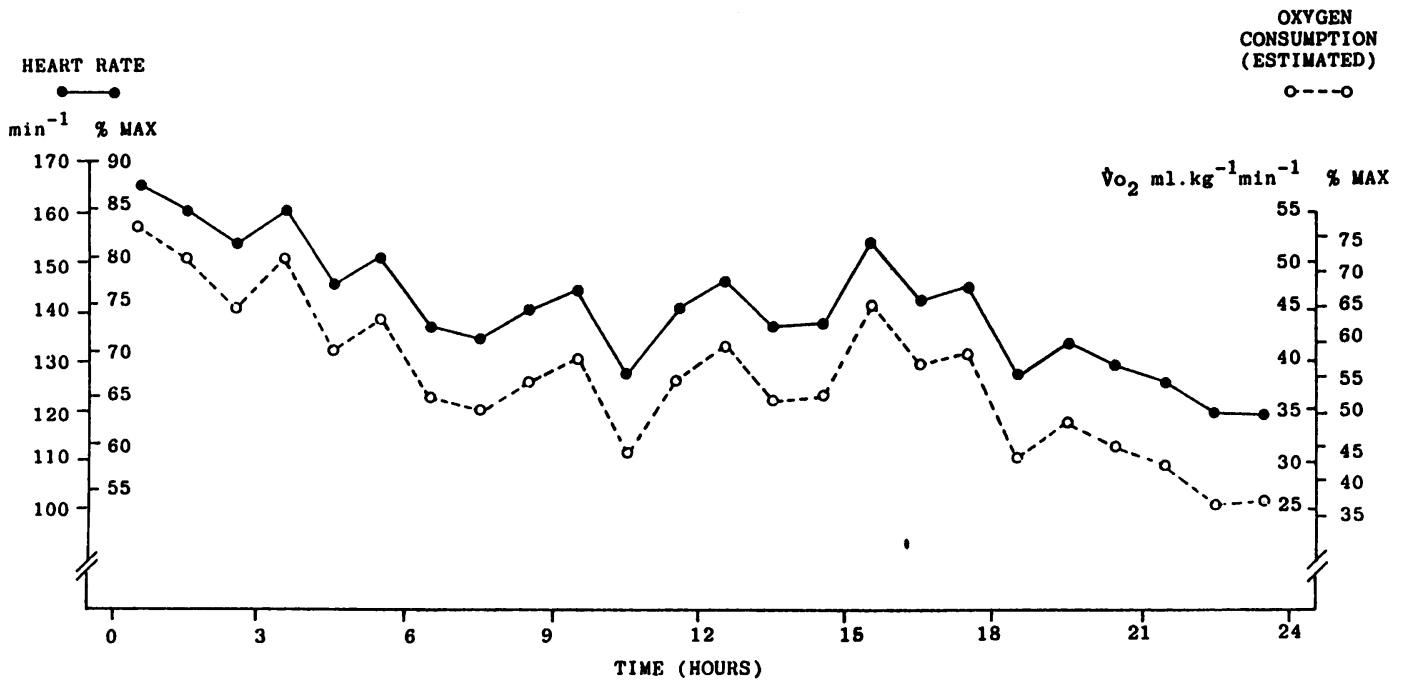

Fig. 3: Physiological event profile during the 24 hour cycle road race.

Using the original heart rate and energy expenditure regression equation generated from laboratory tests, the estimated energy expenditure rates derived from heart rate measures taken during the event were calculated. During the first $6 \mathrm{~h}$ energy expenditure declined from $\sim 82 \mathrm{~kJ} \mathrm{~min}^{-1}$ to $58 \mathrm{~kJ} \cdot \mathrm{min}^{-1}$. Between 6-18 h energy expenditure fluctuated at $\sim 62 \mathrm{~kJ} \mathrm{~min}^{-1}$. Finally during the last $6 \mathrm{~h}$ of the event energy expenditure declined further from $\sim 52 \mathrm{~kJ} \cdot \mathrm{min}^{-1}$ to $40 \mathrm{~kJ} \cdot \mathrm{min}^{-1}$. The overall average throughout the $24 \mathrm{~h}$ event involved an energy expenditure rate of $\sim 58 \mathrm{~kJ} \cdot \mathrm{min}^{-1}$.

The nutritional intake profile of the subject over the
$24 \mathrm{~h}$ period is presented in Table II which represents the relative contribution of liquids, semi-solids and solids to the total energy intake during the event. Pre-event feeding of liquid and semi-solid nutritives accounted for approximately $5 \%$ of the total energy intake. Subsequently the contribution of liquids became increasingly important during the event, particularly during the period 18-24 $\mathrm{h}$. The contribution of solid foods was most pronounced during the period 12-18 $\mathrm{h}$. Whereas semi-solids were most evenly distributed over the four sub-divisions of the whole time period.

The percentage of total energy intake was highest for

\section{TABLE II}

Nutritional intake during a 24 hour cycling road race event (one subject: J.A.S.)

Nutri-

tional

Mode

Liquids

Time Vol Energy

Intervals (ml)

Pre-Event 300

(2 hrs)

$0-6 \mathrm{hrs} \quad 640$

6-12 hrs 1540

$12-18 \mathrm{hrs} 1050$

18-24 hrs 1800

Totals $\mathbf{5 3 3 0}$

Energy

by Wt.

\& \%

$5,480 \mathrm{~kg}$
(kJ) (kCal)

565 (135)

1507 (361)

3571 (854)

2846 (681)

4792 (1146)

13281 (3177)

\begin{tabular}{r|r}
6.4 & 1030 \\
10.7 & 75 \\
29.8 & 1638
\end{tabular}

$50 \%$ | $1.638 \mathrm{~kg}$
Solids

\begin{tabular}{r|rrrr|r}
$\begin{array}{c}\text { \% } \\
\text { Total } \\
\text { Energy }\end{array}$ & $\begin{array}{c}\text { Wt. } \\
(\mathrm{gm})\end{array}$ & $\begin{array}{c}\text { Energy } \\
(\mathrm{kJ})\end{array}$ & $\begin{array}{c}\text { Solids } \\
\text { (kCal) }\end{array}$ & $\begin{array}{c}\text { Total } \\
\text { Energy }\end{array}$ & $\begin{array}{c}\text { Wt. } \\
(\mathrm{gm})\end{array}$ \\
1.3 & - & - & & - & 420 \\
3.4 & 308 & 2177 & $(521)$ & 4.9 & 1060 \\
8.0 & 225 & 3998 & $(956)$ & 9.0 & 760 \\
6.4 & 1030 & 8037 & $(1922)$ & 18.0 & 1050 \\
10.7 & 75 & 837 & $(200)$ & 1.9 & 680 \\
29.8 & 1638 & 15049 & $(3600)$ & 33.8 & 3970 \\
& & & & & \\
$50 \%$ & $1.638 \mathrm{~kg}$ & & & $14.8 \%$ & $3.970 \mathrm{~kg}$
\end{tabular}

Semi-Solids

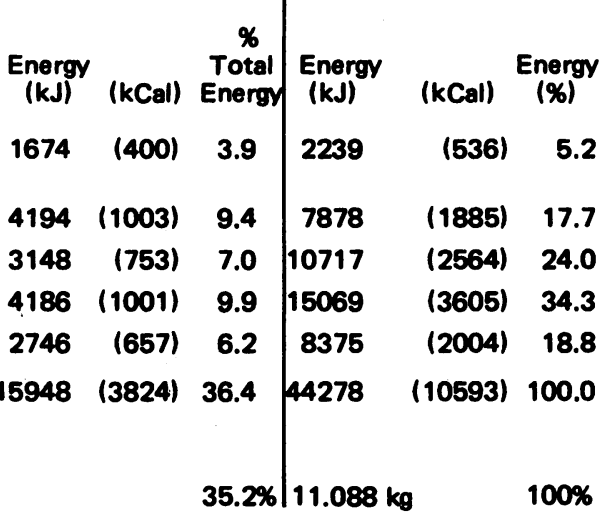


the semi-solids $(36.4 \%)$, followed by solids $(33.8 \%)$ and liquids $(29.8 \%)$. Furthermore the percentage of total energy intake over the event rose steadily during the first three time periods; $0-6 \mathrm{~h}(17.7 \%), 6-12 \mathrm{~h}(24.0 \%)$ and $12-18 \mathrm{~h}(34.3 \%)$, followed by a return close to the initial intake level during 18-24 h (18.8\%).

Overall $11.09 \mathrm{~kg}$ of nutritional materials were ingested during the $24 \mathrm{~h}$ period, of which carbohydrates $(60 \%)$, fats $(30 \%)$ and proteins $(10 \%)$ contributed a total of $44,278 \mathrm{~kJ}$ energy equivalent or $54 \%$ of the estimated energy requirement of the event. Nevertheless, this represented a short-fall of approximately $38,402 \mathrm{~kJ}$ from the estimated $82,680 \mathrm{~kJ}$ energy expenditure incurred by the performance. The difference could be explained by the observed net body weight loss of 1.19 $\mathrm{kg}$ in the subject which could have supplied the remaining $46 \%$ of the estimated energy requirement of the activity involved.

\section{DISCUSSION}

The subject who took part in the study was representative of top class road race cyclists (category 1: British Cycling Federation racing standard), with a $\mathrm{VO}_{2}(69.9$ ml. $\mathrm{kg}^{-1} \min ^{-1}$ ) comparable to other ultra-distance athletes and a previously established record of endurance performance (Table 1), although not including a $24 \mathrm{~h}$ event.

The temporal profile of the race demonstrated some similarities with the only other major study of $24 \mathrm{~h}$ endurance performance by two "ultra-distance" runners (Davies and Thompson, 1979), in that speed declined as a function of distance covered, and the estimated average level of aerobic performance of 38.5 $\mathrm{ml} . \mathrm{kg}^{-1} \mathrm{~min}^{-1}$ (55\% $\mathrm{VO}_{2}$ max) overall was slightly higher than the reported values observed in the runners of the

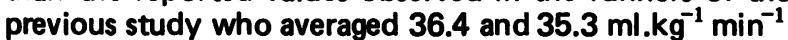
which represented $47 \%$ and $51 \%$ of their respective $\mathrm{VO}_{2}$ max values. Correspondingly, the total estimated energy expenditure of the present study of $82,680 \mathrm{~kJ}$ was somewhat higher than that reported by Davies and Thompson (1979) at $77,829 \mathrm{~kJ}$ in the runner who recorded the greatest distance.

Other attempts to document the physical requirements in "ultra-distance" eventing have been largely restricted to the popular press media rather than sports research literature, so that the present and the previous study represent some agreement in terms of the physiological responses of highly trained endurance athletes to

\footnotetext{
* 44,278 kJ 10,580 kCals

$30,870 \mathrm{~kJ} \sim 7,380 \mathrm{kCals}$

$19,238 \mathrm{~kJ} \sim 4,600 \mathrm{kCals}$

$17,050 \mathrm{~kJ} \sim 4,070 \mathrm{kCals}$

$4,186 \mathrm{~kJ} \sim 1,000 \mathrm{kCals} / \mathrm{hr}$
}

competitive $24 \mathrm{~h}$ racing albeit from two contrasting modes of activity.

The nutritional intake of the subject during the $24 \mathrm{~h}$ period of $44,278 \mathrm{~kJ}$ was considerably higher than previously reported values of $30,870 \mathrm{~kJ}$ per day during a continuous walking exercise task of $100 \mathrm{~h}$ (Thomas and Reilly, 1979), and more than three times greater than the highest values previously reported by the most demanding industrial activity (Lundgen, 1946). Moreover the level of energy intake observed in the present study was more than double the daily average intakes reported for international class cyclists during a survey of representative training periods reported by Stordy (1980) $(19,238 \mathrm{~kJ} /$ day $)$ and Barry et al $(1981)(17,050$ $\mathrm{kJ} /$ day), and similar to the hourly rates of energy expenditure reported by Hedman (1957) in a competitive skiing endurance event $\left(\sim 4,186 \mathrm{~kJ} \mathrm{hr}^{-1}\right.$ over 7 hours). Furthermore the percentage of total energy derived from proteins $(10 \%)$, fats $(30 \%)$ and carbohydrates $(60 \%)$ was markedly shifted towards carbohydrate intake compared with the pattern of intake of the three major nutrient categories reported by Barry et al (1981) (proteins $13.4-15.5 \%$, fats $39.3-42.4 \%$ and carbohydrates 43.8-45.8\%).*

Not surprisingly the continuous nature and hences energy requirement of the activity involved in the present study, together with the need to supply nutrients in a palatable form which could be easily accepted by the digestive system, favoured the use of carbohydrates in liquid and semi-solid form in order to maximise the uptake of a readily usable form of energy substrate (Thomas, 1971; Brooke et al, 1975; Costill et al, 1975 and Ivy et al, 1979). Furthermore, in order to offset fluid losses incurred in prolonged endurance activity which may lead to both thermal and cardiorespiratory disturbance (Costill and Fink, 1974 and Costill et al, 1976), it was necessary to provide a relatively large volume of liquid to overcome the evaporative and respiratory losses, while at the same time providing a suitable medium for nutrient delivery (White et al, 1983 and 1984). Nevertheless, it was only possible to supply a little more than half $(54 \%)$ of the total energy required for the performance, so that the remainder $(46 \%)$ was contributed by the subject's own energy reserves resulting in an equivalent (net) weight loss of almost $1.2 \mathrm{~kg}$.

It was concluded that while the performance of the subject was below that of the event record for $816 \mathrm{~km}$ $(507 \mathrm{~m})$, it was representative of the standard achieved by top $24 \mathrm{~h}$ cycling road race specialists and thus approximates the upper limit of physiological endurance for the mode of exercise concerned. Furthermore the study adds to the fundamental knowledge concerning the physiological and nutritional demands 0 of $24 \mathrm{~h}$ "ultra-distance" eventing and thus provides 
information on those necessary parameters not only required to improve performance, but possibly reduce the risks of impaired performance.

\section{ACKNOWLEDGEMENTS}

The authors would like to thank the Mersey Road
Cycling Club and Road Time Trials Council race officials, technicians of the Human Performance Laboratory of Salford University and the Department of Cardiology at Wythenshawe Hospital, as well as the members of "The Establishment" feeding team and most of all the subject who participated in the study.

\section{REFERENCES}

Barry, A., Cantwell, T., Doherty, F., Folan, J. C., Ingoldsby, M., Kevany, J. P., O’Broin, J. D., O’Connor, H., O’Shea, B., Ryan, B. A. and Vaughan, J., 1981 "A nutritional study of Irish athletes". Brit.J.Sports Med. 15: 99-109.

Brooke, J. D., Davies, G. J. and Green, L. F., 1975 "The effect of normal and glucose syrup work diets on the performance of racing cyclists". J.Sports Med.Phys.Fit. 15: 257-264.

Brooke, J. D. and Green, L. F., 1974 "The effect of a high carbohydrate diet on human recovery following prolonged work to exhaustion". Ergonomics 17: 489-497.

Carpenter, T. M., 1964 . Tables, Factors and Formulae for Computing Respiratory Exchange and Biological Transformations of Energy. The Carnegie Institute, Washington, D.C., Vol. 303 C.

Costill, D. L., Cote, R., Miller, E., Miller, T. and Wynder, S., 1975 'Water and electrolyte replacement during repeated days of work in the heat". Aviat.Space Environ.Med. 46: 795-800.

Costill, D. L., Cote, R. and Fink, W., 1976 "Muscle, water and electrolytes following varied levels of dehydration in man". J.Appl.Physiol. 40: 6-11.

Costill, D. L. and Fink, W., 1974 "Plasma volume changes following exercise and thermal dehydration". J.Appl.Physiol. 37: 521-525.

Davies, C. T. M. and Thompson, M. W., 1979 "Estimated aerobic performance and energy cost of severe exercise of 24 hr. duration". Ergonomics 22: 1249-1255.

Hedman, R., 1957 "The available glycogen in man and in the connection between rate of oxygen intake and carbohydrate usage". Acta Physiol.Scand. 40: 305.

Ivy, J. L., Costill, D. L., Fink, W. J. and Lower, R. W., 1979 "Influence of caffeine and carbohydrate feedings on endurance performance". Med.Sci.Sports 11: 6-11.

Lloyd, E. L., Henderson, W., Lovell, B. and Bryce, G. R., 1977 "Factors affecting performance during an endurance relay". Brit.J.Sports Med. 11: 138-142.

Lundgren, N., 1946 "Physiological effects of time schedule work as lumber workers". Acta Physiol.Scand. 13, Suppl. 41.

O'Hara, W. J., Allen, C., Shephard, R. J. and Gill, J. W., 1977 "Latulippe - a cast study of a one hundred and sixty kilometre runner". Brit.J.Sports Med. 11: 83-87.

Paul, A. A. and Southgate, D. A. T., 1978. In: McCance and Widdowson (eds.) The Composition of Foods. Fourth edition. HMSO, London.

Reilly, T. and Walsh, T. J., 1981 "Physiological, psychological and performance measures during an endurance record for five-a-side soccer". Brit.J.Sports Med. 15: 122-128.

Sengupta, A. K., Sarkar, D. N., Mukhopadhyay, S. and Goswami, D. C., 1979 "Relationship between pulse rate and energy expenditure during graded work at different temperatures". Ergonomics 22: 1207-1215. 
Stordy, B. J., 1980. Personal Communication, 1980. Division of Nutrition and Food Science, Department of Bio-chemistry, University of Surrey. "Nutrient intakes of UK Olympic athletes during training".

Thomas, V., 1971 "Some effects of glucose syrup ingestion upon extended sub-maximal sports performance". Brit.J. Sports Med. 5: 212-215.

Thomas, V. and Reilly, T., 1975 “Circulatory, psychological and performance variables during 100 hours of paced $\overline{\bar{c}}$ continuous exercise under conditions of controlled energy intake and work output". J.Hum.Mov.Stud. 1: 149-155.

White, J. A. and Ford, M. A., 1983 "The hydration and electrolyte maintenance properties of an experimental sports drink". Brit.J.Sports Med. 17: 51-58.

White, J. A. and Ford, M. A., 1984 "The carbohydrate maintenance properties of an experimental sports drink". Brit. $\bar{\omega}$ J.Sports Med. 18: 64-69.

White, J. A., Quinn, G., Al-Dawalibi, M. and Mulhall, J., 1982 "Seasonal changes in cyclists' performance: Part I The GB Olympic Road Race Squad". Brit.J.Sports Med. 16: 13-21.

\section{BOOK REVIEW}

Title: EMERGENCIES IN GENERAL PRACTICE

Authors: A. J. Moulds, P. B. Martin and T. A. I. Bouchier-Hayes

Publisher:

George A. Bogden, Ridgewood, New Jersey, USA, 1983 and in UK: MTP Press, Lancaster. IS 0-942068-07-6

Price: $£ 10.95$

215 pages

Index

Hard cover

I am keeping my review copy of this book in my car, easily accessible, and will probably buy another for the surgery. It is written by three general practitioners for general practitioners and covers most of the emergencies, trivial as well as 0 life-endangering, that one meets in practice. The opening chapters give general advice on the doctor's legal and moral $\overrightarrow{\hat{O}}$ obligations, how to manage telephoned requests, drugs and equipment likely to be needed in an emergency, and the 3 general management of paediatric crises. This is the longest chapter in the book, and a very valuable one. The remainder? of the book lists, in alphabetical order, urgent conditions in the various systems, starting with cardiological emergencies. Each section of each chapter starts with the most likely incoming telephone request, the questions that should beo asked, the differential diagnosis, then in a conspicuous box, the advice given over the telephone, and the management? of the condition; advice and attend surgery the next day; visit and treat or prescribe; admit; what to tell the patient and:the relatives - all good sound practical instructions based on experience.

For future editions a few points need to be added or amended in light of recent practice. In the chapter on obstetric and gynaecological emergencies is a section on contraceptive problems, and though "missed pill", breakthrougho bleeding and coil falling out are mentioned, the real emergency of post-coital contraception is omitted. The new amendments to the Mental Health Act relating to admission under a section need updating.

Although Lt.Col. Bouchier-Hayes has contributed several articles to this journal, there is little direct sports-related emergency treatment in this book, but most sports specific injuries are from overuse rather than acute trauma. I would N regard the book as an essential part of the kit of any doctor accompanying a team on a tour, especially overseas. $N$ Although one would hope that the management of most of the emergencies dealt with would be within the scope of ano experienced GP, the value of the book would be for the hospital doctor coping with conditions in his team outside his field of specialisation. The first aid advice and home management of the less serious illnesses given in the book could also be a big help to the team physiotherapist on tour without a doctor. It must be borne in mind, however, that as doctor is not recognised as such when in another country, and that transporting controlled drugs across a frontier 0 usually requires export and import licences from both countries concerned. 